\title{
University in an oil-dependent state economy: The future of Khuzestan higher education
}

\author{
Hamid Farhadi Rad, Hasan Farazmand, \\ Morteza Afghah, and Yaghoob Andayesh*
}

doi: http://dx.doi.org/10.18543/tjhe-9(1)-2021pp157-198

Received: 29 March 2021

Accepted: 21 June 2021

\begin{abstract}
:
Purpose of the study: The understanding of the complex world and the ability to imagine the futures is the basis for planning and decision-making. Therefore, in this research, the possible future of university in an Iranian oil-dependent economy is studied, and, the best direction for higher education in Khuzestan province is explored.

Methodology: A formative scenario writing research method is used in the current study. The participants were recruited from among Iranian higher education experts purposefully; a series of in-depth interviews including personal and focus group interviews have also been conducted to reach saturation.

Main findings: The results of the present research showed that two main factors affect Khuzestan higher education: dependency on the state economy and increasingly growing social expectation from the university. Khuzestan universities have better select one of these orientations: Conservative University, Enabler University, Adaptive University, and Developmental University. According to the findings of the study, developmental orientation is the preferred scenario for Khuzestan higher education.

Applications of this study: It is argued that the developmental university is the preferred scenario for the future of higher education in Khuzestan Province and a proposal suggests its actualization.
\end{abstract}

* Hamid Farhadi Rad (corresponding author, h.farhadirad@scu.ac.ir) is Associated Professor in the Department of Educational Sciences at the Shahid Chamran University of Ahvaz (Khuzestan, Iran).

Hasan Farazmand (hfrazmand@scu.ac.ir) is Professor in the Department of Economics at the Shahid Chamran University of Ahvaz (Khuzestan, Iran).

Morteza Afghah (m.afghah@scu.ac.ir) is Associated professor in the Department of Economics at the Shahid Chamran University of Ahvaz (Khuzestan, Iran).

Yaghoob Andayesh (andayesh230@ @scu.ac.ir) is Assistant Professor in the Department of Economics at the Shahid Chamran University of Ahvaz (Khuzestan, Iran).

More information about the authors is available at the end of this article. 
Novelty/originality of this study: The applied scenario-based innovative research attempts to reveal the socio-economic role of universities in societies having State-Economy such as Iran, shows all the possible main paths, and finally determines the preferred path for a specific period of time. The current probe can be directly used to lead higher education policymakers of the province and be indirectly employed to help individuals adopt general orientations in higher education, as well as students and researchers who are interested in higher education studies, especially in the field of Higher Education (HE) public policymaking. Finally identified and explained the developmental university that is compatible with Khuzestan higher education situations is another novelty of this research.

Keywords: Higher education; developmental university; entrepreneurship; value creation; state-economy; Khuzestan province.

\section{Introduction}

In all nations, higher education deals with a myriad of controversial issues. The students' employability, ${ }^{1}$ knowledge-based economy and societyengaged university, ${ }^{2}$ job abilities and needs in the fourth generation of the industry, ${ }^{3}$ reducing the number of public funding colleges and universities and, change in social priorities, ${ }^{4}$ are only examples of important issues in the current rapidly changing world. On top of that, the universities in developing countries face additional responsibilities, e.g., they have to link national and local communities to a global community and economy. ${ }^{5}$ For living in this challenging world, modern universities should acknowledge their status and, develop a creative orientation or road map, accordingly.

${ }^{1}$ Hamid Farhadi Rad, Sakineh Shahi, and Forogh Tahmasebi, “An investigation into the requirements and circumstances of decentralization in Ahvaz education: viewpoint, leadership, and human resource," Journal of new approaches in educational administration, 10 no 38 (2017): 57-76, http://jedu.miau.ac.ir/article_3631.html.

${ }^{2}$ Bell Les, Mike Neary, and Howard Stevenson, The Future of higher education: policy, pedagogy, and student experiences, (London and New York: Continuum, 2009), Translated by Jalil Karimi and Peyman Karimi (Tehran: Research Institute for Cultural and Social Studies, 2020).

3 Azmi, A Janwa, Yusri Kamin, M Khair Noordin, and A Nabil Nasir, "Department of Technical and Engineering Education, Faculty of Education, University Technology Malaysia, 81310 UTM Skudai, Johor Bahru, Johor, Malaysia," International Journal of Engineering and Technology 7 no 28(2018): 267-272, Doi:10.14419/ijet.v7i4.28.22593.

${ }^{4}$ Dustin Swanger, 2018. Accessed 20 July 2019, https://www.fmcc.edu/about/ files/2018/08/The-Future-of-Higher-Education-in-the-US2.pdf.

${ }^{5}$ Shu-Hsiang Chen, Jaitip Nasongkhla, and Ana Donaldson, "University Social Responsibility (USR): Identifying an Ethical Foundation within Higher Education Institutions," The Turkish Online Journal of Educational Technology 14 no 4 (2015): 164-172, https://eric. ed.gov/?id=EJ1077652. 
Higher education as a social institution has a long history in Khuzestan province. Founded in 530 AD, Jundi-Shapur University in Khuzestan Province has been one of the oldest universities in the world, and many Iranian and Indian scholars have taught there. At that time, various sciences such as medicine, philosophy, theology, mathematics, music, governance, and agriculture were part of the curriculum of this university. After that remarkable period, the revival of the university began in $1955 \mathrm{AH}$ with the establishment of the Faculty of Agriculture and the admission of 40 students in new courses. Then, in 1956, preparations were made for the establishment of a medical school. ${ }^{6}$ Today, more than one hundred universities or university units are operating in Khuzestan province with different qualities and strategies. ${ }^{7}$ Fundamental changes such as financial and political dependence on the central government, differing studentpopulation, theinternationalization of universities, and the local community expectations from the university have highlighted the need to revise the university's guidelines in this province. Higher education in Iran has many sub-systems including State Universities, Islamic Azad University, nonprofit non-governmental university, and alike. Approximately $46 \%$ of students are educating in state universities that financially supported by government. ${ }^{8}$ An inherent problem from an intra-system perspective is that in Iran, the universities have not been very successful in decreasing their financial dependence on the government. This is not surprising given that the financial dependence of the universities on the government is a major and, historical policy in Iran. In the other words, in Iran, the government is the main finance supplier of the university sector and, the prerequisite for granting credits to universities is depend on the number of students entering universities. In addition to fundamental changes such as new technologies and the diversity of university responsibilities aaccording to the reports of the Parliament Research Centre with the cooperation of Organization of Economic Affairs in Iran, the international sanctions during 2012 had serious effects on Iran higher education. ${ }^{9}$ Therefore, universities in Iran have a great desire to get out of financial dependence on the government.

\footnotetext{
${ }^{6}$ Shahid Chamran University of Ahvaz, Accessed 5 April, 2020, http://scu.ac.ir/.

7 The Board of Supervision, Evaluation and, Quality Assurance of the Universities in Khuzestan, Accessed 5 April 2020. http://scu.ac.ir/web/nezaratostan

${ }^{8}$ Institute for Research and planning in Higher Education, Accessed 2019, https://irphe. ac.ir/content/1921/

9 Amir Khadem Alizadeh, Hamideh Amadeh, and Mahboobeh Baghalian, "The impact of economic sanctions on employment in Iran," Economic Strategic Research Institute 11, no 3 (2014): 79-104 https://www .civilica.com/Paper-IECEUS02-IECEUS02_069.html.
} 
In the 21 st century, university is an integral part of the development process, and the sustainable development of countries revolves around a responsive and efficient education and research system. Therefore, investing in higher education is one of the highly valued areas of practice. ${ }^{10}$ For instance, Khosravi et al. argued that the higher education in Iran has expanded beyond the masses and has entered the post-masse stage, but this increasing expansion has led to social demands without measuring its social, economic, and cultural impact. The issue of investing in higher education is so important that some scholars have considered it to be the most important type of investment which contributes greatly to the social and economic development of a society. ${ }^{11}$ These arguments and their related theoretical underpinnings given, one might see that the development of higher education has been on the agenda of many governments, however, higher education in Iran, and consequently in Khuzestan province, faces two major issues:

The first is that Iranian universities generally rely on government funding; as a result, people and the public expect the government to allocate these resources and facilities properly, and higher education policymakers to adopt the best policies and strategies in order to achieve the desired goals of the society. ${ }^{12}$ Although the development of higher education has many benefits, the unbalanced development, disregard for cultural, social, and economic impacts as well as downgrading the emerging and increasing social demands, can have serious consequences for the country and the region. ${ }^{13}$ Graduate unemployment postpones some normal stages of young people's lives such as marriage and employment and enhanced social stress caused by unemployment. ${ }^{14}$ Unbalanced development of universities led to declining

${ }^{10}$ Mostafa Moein, Higher Education Policy, and Development (Tehran: Research Institute for Cultural and Social Studies, 2018).

${ }^{11}$ Mahboobeh Khosravi, Kourosh Fathi Vajavgah, Hasan Maleki, and Daryoush Nouroozi, "Investigating the Adoption of Curriculum Innovations in Higher Education System (Case Study: Curriculum Revision Code of Iranian Universities)," Journal of Educational Psychology 9, no 27 (2013): 135-166, http://ensani.ir/fa/article/319810.

${ }^{12}$ Ebrahim Hajipoor, Lotfollah Frouzandeh, Hasan Danaee Fard, and Asghar Fani, "Designing a Pathological Pattern for Public Policy Implementation in Iran," Military Management Quarterly 15, no 28 (2015): 1-23, https://www.sid.ir/fa/Journal/ViewPaper.aspx?id=314990.

${ }_{13}$ Eisa Samari, Mohammad Yamani Dozi Sarkhabi, Ebrahim Salehi Omran, and Golam Reza Geraei Nezhad, "Investigating and identifying the effective factors in the process of "university development" in Iranian public universities," Educational planning studies 2, no 4 (2014): 67-100. http://eps.journals.umz.ac.ir/article_760.html.

${ }^{14}$ Hamid Farhadi Rad, Sakineh Shahi, and Forogh Tahmasebi, "An investigation into the requirements and circumstances of decentralization in Ahvaz education: viewpoint, leadership, and human resource," Journal of new approaches in educational administration 10, no 38 (2017): 57-76, http://jedu.miau.ac.ir/article_3631.html. 
quality of educations and researches. Changes in the original foundations of the academic community and research disruptions, ${ }^{15}$ graduate unemployment and migration and brain drain, ${ }^{16}$ and waste of financial and human capita 17 are just some of these unfortunate consequences.

The second issue is the expectations of regional and local stakeholders of higher education. Normally, it is expected that universities consider regional potentials and talents and the policies proposed based on them..$^{18}$ The issue of simultaneous attention to the national and regional dimensions is rooted in a successful global approach to higher education that has emerged since 1990, making regional development one of the university's missions and responsibility. ${ }^{19}$ This alternation of mission continued to the extent that some universities intended to defeat local crimes and/or, in some areas, they played a major role in providing jobs opportunities. For example, the University of Georgia was the second largest employer in 2008, and also, it was the Emory University in 2009, and Austin University in 2002 had important role in employability. ${ }^{20}$

The two main issues, namely responsibility and accountability for government funding and attention to regional needs, are interconnected in one crucial area. In other words, one of the best ways to portray modern and higher education is to consider it as a social organization that has many functions including the provision of higher education and learning areas, training graduates to undertake social careers, producing knowledge and culture through research, and increasing the emphasis on innovation, entrepreneurship and value creation. ${ }^{21}$ Entrepreneurship is an emerging field,

${ }^{15}$ Somayeh Fereidouni, Social implications for the quantitative development of higher education (Tehran: Institution for research and planning in Higher education, 2017), https:// irphe.ac.ir/files/site1/files/Speech/1396.06.28.pdf.

16 Mohammad Amin Ghaneirad, "Uneven development of higher education: Unemployment of graduates and migration," Social Welfare Quarterly 4, no 15(2005): 169208, http://refahj.uswr.ac.ir/article-1-1909-fa.html.

17 Mohammad Soheil Sarv, Jafar Hezarjeribi, Mohammad Taghi Karami Ghahi, and Ardashir Entezari, "The Ratio of Higher Education Development Policies and School Demand," Social development and welfare planning 11, no 41 (2020): 33-72. doi:10.22054/ QJSD.2019.11838.

${ }^{18}$ Mohammad Ali Ghalandar, Entrepreneurship University indicators, Master Thesis in Education, Shahid Chamran University Ahvaz, Iran (2010).

${ }^{19}$ Hamid Reza Arasteh and Elham Amiri, "The Role of Universities in Sustainable Development Education," Journal of Transplanting Science (Nasha-e-Elm) 2, no 2 (2012): 29-36

${ }^{20}$ Sayed Ghasem Hasani, "University and Regional Development: Mazandaran University," (Tehran: Institute for Cultural and Social Studies, 2017).

${ }^{21}$ Harold Perkin, History of Universities. Vol. 18, in International Handbook of Higher Education (Springer, 2007) doi:10.1007/978-1-4020-4012-2_10. 
it has also been strongly emphasized in the upstream documents. ${ }^{22}$ Accordingly, the university becomes part of the communication network and enacts to manage interdependencies on the environment and society to create a new valued proposition. ${ }^{23}$ Therefore, higher education is one of the modern social institutions that is expected to participate in the social and economic development of the society. But to fulfil this mission, it faces many problems; to overcome the problems, it needs to develop a guideline. Therefore, it could be said that the main purpose of the present study is to find out how higher education of Khuzestan province can contribute to the socio-economic development of this region. To answer this question, one could argue that higher education has to formulate a guideline in the face of existing and emerging needs. The guideline aims to picture the future in a particular field formed by the careful analysis of that field, and to direct the movements in that field and ultimately empower stakeholders. ${ }^{24}$ In sketching this guideline, two important issues can be addressed. Firstly, higher education policymakers have to determine the factors and drivers required to develop the guideline in a local and national community. Second, the guideline for optimal future scenarios means choosing the most desirable path from a diverse set of possible paths for an organization. ${ }^{25}$ Therefore, the purpose of the current study is to create alternative scenarios and propose the preferred one for higher education in Khuzestan province.

\section{Theoretical underpinnings}

The creation and expansion of higher education can be explained based on the existing theoretical foundations, including the ideas of Human Capital Theory advocates such as Freeman, Denison, Psakharopolus, Hinchliffe, Williams, and Gordon. The theory of Human Capital (HCT) introduces education as the main factor of economic empowerment. ${ }^{26}$ Proponents of this theory, such as Gary Becker, Theodore Schultz, and Adam Smith, believe that education has a significant impact on the social,

${ }^{22}$ Fifth and Sixth Five-Year Development Plan of the Islamic Republic of Iran, 2011-2020

${ }^{23}$ K.B. Akhilesh, Co-Creation and Learning Concepts and Cases, (Springer: 2017).

${ }^{24}$ Robert Galvin, "Science Roadmaps" Science 280, September 25, 2020, https://www. science.org/ doi/10.1126/science.280.5365.803a.

25 Jerry J Herman and Janice L Herman, Making Change Happen: Practical Planning for School Leaders (California: Corwin Press, 1993).

${ }^{26}$ Fatemeh Sharifi A. M., Abasalt Khorasani, Kourosh Fathi V., and Ebrahim Salehi O., "Employability skills of Academic Graduates: an Exploratory Mixed Approach," Journal of Theory and Practice in Curriculum 13 no 7(2019): 29-52. 
economic, and political development of the society. ${ }^{27}$ Therefore, the HCT has provided an acceptable basis for the creation and expansion of universities. It could, therefore, be argued that, although higher education and the institutions of producing knowledge have existed throughout human history, the formation and growth of modern universities have begun several centuries ago in the West following the economic and social changes. Western societies have sought to address the challenges, problems, and needs of their leaders by using various sciences and establishing science centres. Thus, with the development of science, universities and higher education centres have gradually emerged as social institutions in the modern society. ${ }^{28}$ Today, higher education represents a type of investment in human resources that contributes to the national development by enhancing the knowledge, skills, and attitudes required from the staff and by nurturing the future workforce.$^{29}$ To achieve these important goals, various academic models including Humboldt, Napoleon, and the AngloSaxon (British model) have been spread throughout the world during the 19th and 20th centuries and have had enormous impacts on many countries around the world (Sam and Sijde 2014). Subsequently, Americans adopted these three models, establishing a Native American model (market-based model) in the early 19th century for higher education.

In addition to being research-centric, market-based universities have considered three other features including; "useful knowledge" that is rooted in the spirit of American pragmatism, "a close relationship with the local community", and "linkage to the country's economy". These three attributes give an independent identity to such universities. ${ }^{30}$ Carlsoon et al. believe that Humboldt's thinking has penetrated everywhere, especially the US, and affected most universities during the 19th century. American universities were rapidly moving towards decentralization, pluralism, and market-based

${ }^{27}$ Mostafa Emadzadeh, Economics of Education (Esfahan: Jahad Daneshgahi, 2016).

${ }^{28}$ Ebrahim Salehi O, and Hosein Chaharbashlou, 2011, "Studying University-Industry Relations in Iran: A Comparative Study Based on Successful Countries' Experiences.” Paper presented in The first International Conference on Management, Foresight, Entrepreneurship and Industry in Higher Education was held on May 17, 2011 by the University of Kurdistan in Sanandaj.

29 Palmeyra Josvisin, Trans McLaughlin, David Bridge, Roberta Josvisius, and Julant Stankovisius, Higher Education, and National Development: Universities and transitional societies (Routledge, 2012), Translated by Reza Simbar (Tehran: Cultural and Social Studies Research Institute, 2014).

${ }^{30}$ Mohammad Ali Ghalandar, Entrepreneurship University indicators 
competition. They altered their strategies to employing higher education. ${ }^{31}$ Turner states that American universities had a unique structure that was created by combining British, German, and other European academic systems with local initiatives. ${ }^{32}$ Consequently, in the early twentieth century, a new model of higher education with some unique features was introduced which rapidly affected the higher education system throughout the world. Clark has highlighted the impact of the market on universities and believed that today's universities help increase their independence by expanding relationships and engaging in social and economic activities. ${ }^{33} \mathrm{He}$ called these types of universities the Entrepreneurial University, and the only way for universities to survive the current state of affairs is to rely on university entrepreneurship products and the flexibility and adaptability of the organizational structure of universities. In this way, he encourages traditional university models to be transformed into entrepreneurial (market-based) universities. ${ }^{34}$ The university was thus introduced as a major player in the national and local development system, and as such, social activities became a very important part of the university's existence.

As a result, given the political and environmental pressures, labour and capital market factors, responsiveness and accountability of universities, and the needs and demands of stakeholders, the academic community of universities was overwhelmed. It is not surprising, then, to consider the university as a "changing ecosystem", as stated by Locker. The root of these developments can be traced to fundamental changes in the conditions and needs of a society. Etzkowitz and Leydesdorff ${ }^{35}$ believe that a structural change has taken place in European universities and that universities have gradually shifted from their traditional role of teaching and research to a third mission of commercialization and transfer of knowledge for economic development. Figure 1 illustrates the changing academic paradigm and the mission of the university shifting from

${ }^{31}$ Chanphirun Sam, and Peter van der Sijde, "Understanding the concept of Entrepreneurial university from perspective of higher education models," Higher Education 68, no 6 (2014): 891-908, DOI 10.1007/S10734-014-9750-0.

${ }^{32}$ Chanphirun Sam and Peter van der Sijde, Understanding the concept of the entrepreneurial university from the perspective of higher education models

${ }^{33}$ Barton Clark, "The Entrepreneurial University: New Foundations for Collegiality, Autonomy, and Achievement." Higher Education Management 13 no 2 (2004): 23-36.

${ }^{34}$ Rubins, Ira. "Risks and Rewards of Academic Capitalism, and the Effects of Presidential Leadership in the Entrepreneurial University" https://www.semanticscholar.org, (2007): 1-5, Accessed April 28 (2019).

${ }^{35}$ Henry Etzkowitz, and Loet Leydesdorff, "The transformation of university-industrygovernment relations” Electronic journal of Sociology 5 no 4 (2001): 101-117, http://www. sociology.org/content/vol005.004/th.html. 
the simple to the complex environment and from the secure environment to the uncertain environment in a matrix structure.

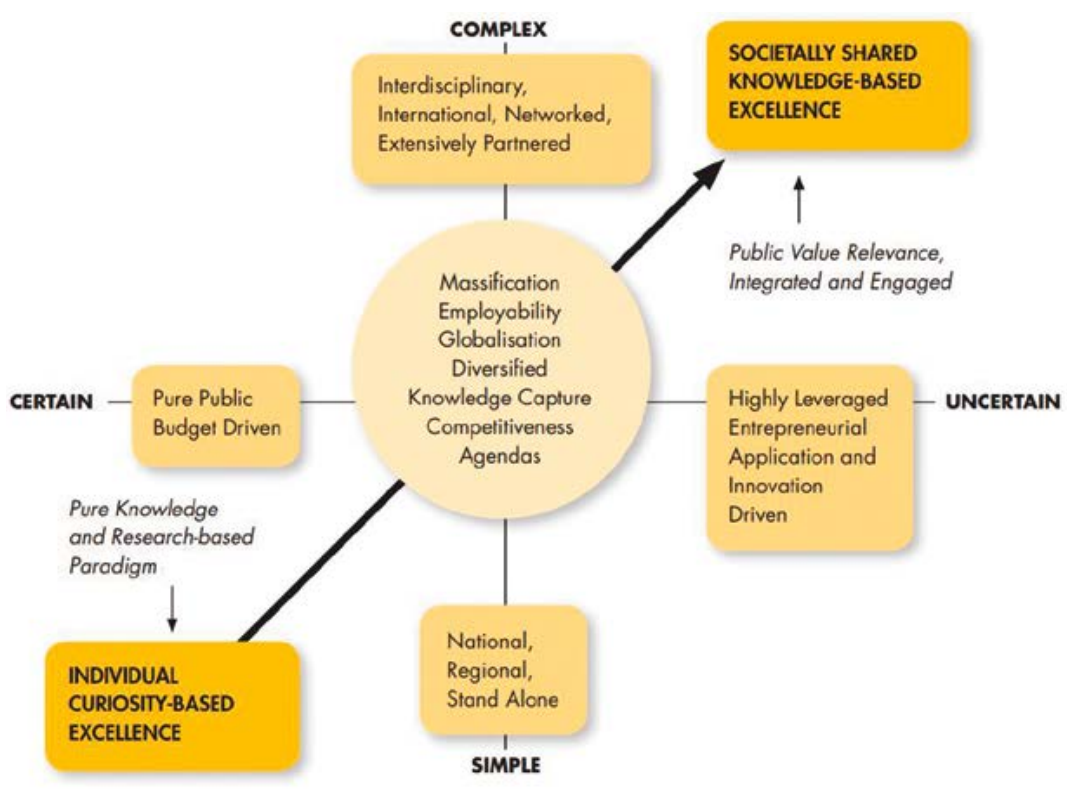

Figure 1

Changing the academic paradigm ${ }^{36}$

As a result of strengthening the theoretical foundations and the functioning of social factors such as, increasing pressure on the government, increasing number of graduates, changing expectations of higher education stakeholders, changing market needs, responsiveness and accountability to society, and quality revolution and productivity, the university partnerships were enhanced to resolve local and regional issues and appeared in the form of the entrepreneur university. At the same time, the new approach to the entrepreneurship has been associated with a value creation approach, so that if entrepreneurship is not based on community values, its consequences will

${ }^{36}$ Allan Gibb, Gay Haskins and Ian Robertson, Leading the entrepreneurial university: Meeting the entrepreneurial development needs of higher education institutions (New York: Springer, 2009). 
not be worthwhile. From the underlying epistemological issues to economic issues, this new approach encompasses all fields of science and political culture. ${ }^{37}$ The entrepreneurial and value-creating university seeks to intelligently identify, evaluate, and efficiently exploit opportunities based on economic, cultural, and sociological values.$^{38}$ Entrepreneurship, in its new sense and the credited identity with its wrathful repercussions on value creation, has received widespread acceptance from universities and academic communities and is expected to achieve the aspirations of university and university work (with the support of various sections of society). ${ }^{39}$

Iranian education has become efficient and organized to empower human beings, but the divergence of universities from the real needs of society and the disregard for the job market has left students without a sense of direction and a start-up, so that they merely seek job opportunities but do not create them..$^{40}$ Therefore, universities are expected to develop creative thinking, train positive and adventurous attitudes, avoid destructive thinking, encourage perseverance, acquire effective skills to overcome the barriers on the way of the students, and set up entrepreneurship training centres to end the current difficulties of the society. Perhaps the greatest community expectation from the university is the economic, cultural, and social values created by research. ${ }^{41}$ Universities pave the way for collaboration and promote the link between industry and academia by creating entrepreneurial culture and orientation for faculty and students, setting up science and technology parks, growth centres, and start-ups. Entrepreneurship not only leads to the creation of economic and material values but also the value of entrepreneurship as an engine of social, political, and cultural development.

Entrepreneurs prioritize the social value creation. By following both commercial and social objectives, entrepreneurs seek to contribute to the natural and social resources..$^{42}$ In addition to theoretical foundations, many

${ }^{37}$ Mohammad Taghi Amini, Mohammad mahdi Parhizgar, Mehran Rezvani, and Saeed Farjam, "Designing a Conceptual Model of Value Creating Entrepreneurship," Modern Marketing Research 5, no 1(2015): 19-30.

${ }^{38}$ Amini, Mohammad Taghi, Mohammad mahdi Parhizgar, Mehran Rezvani, and Saeed Farjam, Designing a Conceptual Model of Value Creating Entrepreneurship.

${ }^{39}$ Mohammad Ali Ghalandari, Entrepreneurship University indicators.

${ }^{40}$ Mohammad Azizi, "Analytical-Comparative Study of the Performance of Top Entrepreneurship Centers of American Universities and Entrepreneurship Centers of Selected Iranian Universities.” Journal of Innovation and Value Creation 4 no 8 (2016): 21-32.

${ }^{41}$ Mostafa Moein, Higher Education Policy, and Development

${ }^{42}$ Steven Brieger, Anne Baro, Giuseppe Criaco, and Siri Terjesen, “Entrepreneurs' age, institutions, and social value creation goals: A multi-country study" Small Business Economics, no 57 (2021): 425-453, doi.org/10.1007/s11187-020-00317-z. 
studies including ${ }^{43,44,45,46}$ show that universities can improve entrepreneurship and value creation in the society through education. Dealing with entrepreneurship and value creation requires the university's financial independence. ${ }^{47}$ Approaches based on teaching and research in universities require a more comprehensive approach to organizations outside the university ${ }^{48}$ For universities to be innovative about their environment, to be creative with innovative ideas, to value the job market, to persuade industries to invest in higher education, entrepreneurial universities should have an operational vision in education that will help link conceptual knowledge to entrepreneurial and creative enactment. ${ }^{49}$ They need to focus on the sensory, emotional, and affective aspects of the teaching and learning processes to build creativity and innovation in students..$^{50}$ The entrepreneurial university must foster an entrepreneurial spirit and innovation in students and faculty and integrate the university's inputs, processes and outputs so that both university executives and leaders, as well as the outside community and business environment, pledge themselves to the university's commitment to entrepreneurship and value creation. Today, entrepreneurial and value-creating universities have become an effective tool in solving the problems of educated societies, which increasingly emphasize the value of science.

${ }^{43}$ Hao Jiao, "A conceptual model for social entrepreneurship directed toward social impact on society," Social Enterprise Journal 7 no 2 (2011): 130-149, doi.org/10.1108/ 17508611111156600 .

${ }^{44}$ Saul Estrin, Tomasz Mickiewicz, and Stephan Ute "Human capital in social and commercial entrepreneurship" Journal of Business Venturing, no 31 (2016): 449-467, https:// doi.org/10.1016/j.jbusvent.2016.05.003.

${ }^{45}$ May Portuguez Castro, Carlos Ross Scheede, and Marcela Georgina Gómez Zermeno, "The Impact of Higher Education on Entrepreneurship and the Innovation Ecosystem: A Case Study in Mexico." Sustainability, 11 no 20 (2019): 1-17.Doi: https://doi.org/10.3390/su11205597.

46 Jantje Halberstadt, Jana-Michaela Timm, Sascha Kraus, and Katherine Gundolf, "Skills and knowledge management in higher education: how service learning can contribute to social entrepreneurial competence development," Journal of Knowledge Management 23, no 10 (2019): 1925-1948. Doi.org/10.1108/JKM-12-2018-0744.

${ }^{47}$ Leo Aldianto, Grisna Anggadwita, and Aang Noviyana Umbara, "Entrepreneurship education program as value creation: Empirical findings of universities in Bandung, Indonesia," Journal of Science and Technology Policy Management, 9 no 3 (2018): 296-309, doi:10.1108/ JSTPM-03-2018-0024.

${ }^{48}$ Mohammad Ali Ghalandari, Entrepreneurship University indicators

49 Leo Aldianto, Grisna Anggadwita, and Aang Noviyana Umbara, "Entrepreneurship education program as value creation: Empirical findings of universities in Bandung, Indonesia."

${ }^{50}$ Tatiana Chemi and Lone Krogh, Co-creation in Higher Education: Students and Educators Preparing Creatively and Collaboratively to the Challenge of the Future, Creative Education Series Vol. 6 (Aalborg: Aalborg University, 2017). 
People in an Iranian society normally expect university graduates to be technically experts and socially responsible and innovative. According to the fourth industrial revolution, these skills such as negotiation skill, cognitive skill, service-orientation, teamwork, emotional intelligence, shared decisionmaking, critical thinking ability, and complex problem-solving abilities are necessary for $21^{\text {st }}$ century. ${ }^{51}$ In the other word the innovative skills such as teamwork ability, creating international communications, and the skills to use software platforms probably opens up new windows for the youths around the world. ${ }^{52}$ The presence of individuals with high levels of expertise and social skills seems essential for enabling efficiency, entrepreneurship, and optimum enhancement of a context that is based on complicated technical and static systems. As such, quality instruction is required to prepare future human resources, and this is possible via the higher education system..$^{53}$ However, university graduates reflect a lack of coordination between the society and the workplace expectations. ${ }^{54}$ There is no consistency between the topics of the courses and the jobs' requirements. ${ }^{55}$ The training processes and materials are not consistent with the necessary skills and abilities in the workplace. ${ }^{56}$ The instructions are not in line with the market and industry demands. ${ }^{57}$ The graduates do not acquire adequate practical

51 Amiron, Evarina, Azlan Abdul Latib, and Kamalularifin Subari, "Industry Revolution 4.0 Skills and Enablers in Technical and Vocational Education, and Training Curriculum" International Journal of Recent Technology and Engineering (IJRTE) 8 no 1(2019): 485-492.

52 Punit Renjen and Sarah Brown, Preparing tomorrow's workforce for the Fourth Industrial Revolution, For business: A framework for action, (Deloitte Global and the Global Business Coalition, 2018).

${ }^{53}$ Mahmoud, Yaghoubi, and Hossein Motahharenejad, "The main requirements in developing Iranian engineering training strategies" Iranian of engineering education, 13 no 51(2011): 31-51.

${ }^{54}$ Mehdi Feyz, and Mehdi Bahadorinejad, "Identifying the desired professional qualifications of engineering graduates in Iran: Case Study Sharif University of technology graduates" Iranian Journal of engineering education 12 no 46 (2010): 37-68, http://ijee.ias.ac. ir/article_673.html

${ }^{55}$ Reza Maknoun, 2001. "Country higher education employment and development strategy", Proceedings of the Strategic Congress of Scientific Development of Iran, Tehran: Ministry of Science, Research and Technology, I ran science promotion headquarters 1400

${ }^{56}$ Ramin Rahmani, and Ali Nazari Tavakoli, 2003, "The challenges of the higher education system in relation to the employment of graduates," The first conference on employment and the countrys higher education system, Tehran: Tarbiat amodares university.

${ }^{57}$ Hosein Momeni Mahmoei, Ali Shariatmadari, and Ezatullah Naderi, "Competencybased curriculum in higher education," Quarterly Educational of higher education curriculum, 5 no 17 (2008): 129-156. 
experience while studying. ${ }^{58}$ The focus is on the knowledge enhancement rather than on the skill and attitude expansion relevant to the professional working, ${ }^{59}$ and university training does not play any significant role in the students' employment skills ${ }^{60}$ In addition, Mousavi et, al. argued that the barriers to entrepreneur university ecosystem development in Iran are: financial, structural, research, administrative, communication, traditional education and organizational culture. ${ }^{61}$ Also based on Mohammad Shafi et, al. The Iranian universities' curricula are not skill-based and job creating so need to be revised. ${ }^{62}$ In general, higher education theoretical foundations show that universities must play a vital role in the economic and social developments of nations; but the result of researches shows deficiencies in the university system. Therefore, developing a realistic guideline for higher education during the $21^{\text {st }}$ century will be an essential need to adjust the local society with a global economy and society.

\section{Methodology}

\section{III.1. Research method}

The present study is considered applied research in terms of purpose. The purpose of such research is to provide practical solutions to specific problems or to predict possible future scenarios to address a particular issue. Since the present study intends to draw a picture as realistic as possible for higher education in Khuzestan by analysing the environmental situations and studying the factors affecting the future social life of Khuzestan province, it

${ }^{58}$ Abolghasem Barabadi, Malek Mohammadi, and Ali Asadi, "Educational, social and cultural barriers to employment of agricultural graduates." Journal of Economics, labour, and society No109 (2009): 92-100.

${ }^{59}$ Hosein Memarian, 2011, "Mechanism for evaluating engineering education programs: from ideal to reality," Fifth Conference Quality Assessment in the University System, Campus of Technical Colleges, Tehran: University of Tehran, https://uteq.ut.ac.ir/documents/30787/ 792815/8-Memarian.pdf.

${ }^{60}$ Hamzeh Nozari, and Alireza Karimi, "The role of formal and informal relations (social relations network) in the employment of students of Kharazmi University," Journal of Social welfare 17 no 64 (2017):159-194.

${ }^{61}$ Seyyed Hosein Mousavi, Ebrahim, Salehi Omran, Seyyed Mahsa Mousavi, and Maghsoud Ferasatkhah, "Identifying the Barriers to Entrepreneurial University Ecosystem Development," Journal of Teaching in Marine Sciences 6 no 4 (2019): 35-51. http://rmt. iranjournals.ir/article_38347.html?lang=en

${ }_{62}$ Mahboobeh Mohammad Shafi, Mohammad Reza Neyestany, Ebrahim Jafar, and Vida Taghvaei, "Evaluating the Quality of the Curriculum in Skills Training," New Educational Approaches 15 no 31 (2020): 70-102. https://nea.ui.ac.ir/article_25374.html?lang=fa. 
is believed to be practical research. From the methodological point of view, the present study falls into the category of descriptive-analytical research that has used the scenario writing method to present the findings using a phenomenological analysis approach. According to Ogilvy and Schwartz, scenario writing predicts the future based on possible future events and is therefore, a useful tool welcomed by planners for planning purposes based on nonlinear approaches.$^{63}$ In the present study Fahey and Randall's pattern was adopted for the purpose of scenario development. Accordingly, scenario development takes place in six steps. The first is statement of the problem, which in the current research took the form of determining and planning the Higher Education road map in Khuzestan. The second step was to identify and categorize the key drivers. For this purpose, different means and techniques like, Cross Impact Analysis (CIA), and Causal Layered Analysis (CLA) are generally used. However, since in the present study multiple factors could be analysed as exerting influence on the future of Higher Education in Khuzestan at different layers, CLA was used and the key drivers were categorized into four classes of objective facts, institutional factors, factors related to the social discourse, and transnational factors. ${ }^{64}$ The main reason for using CLA was to enable a better understanding of the future and its complexities. ${ }^{65}$ The required data were collected using the written resources and conducting in-depth interviews with the experts. The third step was to formulize the drivers. At this stage, a focal group was formed and after several sessions of intensive debate and discussion between the Higher Education and Economic Development intellectuals, key environmental and institutional factors were formulized. Two major influential factors on the future of Higher Education, i.e., state economy dependent on the oil sales and University internal preferences were introduced as the main axes navigating the future of Higher Education in Khuzestan. The fourth and fifth steps were to determine the logic of the scenario and the possible futures. By the sixth step, the Developmental University scenario was presented and interpreted as the preferred scenario.

63 James Ogilvy, and Peter Schwartz, Plotting Your Scenarios, In L. Fahey and R. Randall (Eds.), Learning from the Future, Edited by L. Fahey and R. Randall, (California: John Wiley and Sons, 1998).

${ }^{64}$ Abdolmajid Keramat Zadeh, "The Role of Cognitive Metaphors in FS: An Analysis of Sohail Inayatallh's Viewpoints," Journal of Iran Futures Studies 1 no 1 (2016): 15-32. https:// jfs.journals.ikiu.ac.ir/article_1155.html?lang=en.

65 Mohammad Hoseini Moghadam, 2017. Iranian University in the international Environment: Internationalization of Iranian Higher education, and future of university in Iran, (Tehran: Research centre for Social-Cultural Studies, 2017). 


\section{III.2. Participants}

To answer the research questions purposefully and descriptively, scholars in the field of higher education and intellectuals in the field of economics were invited to participate in this study. They were selected purposefully based on their knowledge, expertise, familiarity, and theorizing in the Khuzestan social context, applying the snowball sampling technique. The participants are:

\section{Table 1}

Scheme of research participants

\begin{tabular}{|c|l|}
\hline code & \multicolumn{1}{|c|}{ Specialty and field of activity } \\
\hline 1 & $\begin{array}{l}\text { Ph.D. in higher education management and policy expertise in Iranian } \\
\text { higher education }\end{array}$ \\
\hline 2 & $\begin{array}{l}\text { Ph.D. in educational management with a specialization in policy and } \\
\text { strategic planning in higher education }\end{array}$ \\
\hline 3 & $\begin{array}{l}\text { Doctorate of economics in higher education with a specialization in } \\
\text { research and planning in higher education }\end{array}$ \\
\hline 4 & $\begin{array}{l}\text { Doctorate of higher education with specialization in higher education } \\
\text { planning and development }\end{array}$ \\
\hline 5 & $\begin{array}{l}\text { Doctorate of educational management and entrepreneurship specialist } \\
\text { in higher education }\end{array}$ \\
\hline 6 & $\begin{array}{l}\text { Doctorate of management and specialty in entrepreneurship and future } \\
\text { research }\end{array}$ \\
\hline 7 & $\begin{array}{l}\text { Doctorate of educational planning and strategic planning specialist in } \\
\text { higher education }\end{array}$ \\
\hline 8 & $\begin{array}{l}\text { Senior expert, managing director, international consulting company, } \\
\text { member of the board of directors of Iran-Germany chamber of } \\
\text { commerce and industry }\end{array}$ \\
\hline 9 & $\begin{array}{l}\text { Doctorate of higher education management and higher education } \\
\text { planning and development specialist }\end{array}$ \\
\hline 10 & $\begin{array}{l}\text { Doctorate of curriculum and specialist in educational content and } \\
\text { future research }\end{array}$ \\
\hline
\end{tabular}

\section{III.3. Interview protocol and data gathering process}

The future of higher education in Khuzestan is affected by many variables and factors. In this research, semi-structured in-depth interviews with experts and intellectuals were the main instrument for the data collection 
and identification of the probable factors. Interview protocol and data gathering process were as follows:

Before the interview: purposeful identification of the faculty members and other experts, obtaining faculty approval, respecting the conduction of all interviews and principles of research ethics, sending questions to faculty upon request, providing them with the appropriate time and place for conducting the interview process with the consent of the interviewee, giving the interviewees general information about the subject under study and the necessity of doing so in Khuzestan province universities, were the steps taken before conducting the interviews.

Interview stage: consists of 1 . Providing a general explanation of the main dimensions of the research to clarify the general outlines of the research topics, recording and transcribing the statements of the interviewers with appropriate tools (audio recording software), providing questions on the first topic, and asking questions about the first topic of research, i.e. the future guideline of Khuzestan Higher education. The structured part of the interview questions are as follows:

1) What are the main factors affecting Khuzestan's Higher education to entrepreneurship and value creation?

2) How could universities pay attention to these factors for a better future?

The final stage: included the following: the recordings were transcribed from the recorded file, developed an expert report, and then studied several times; a satisfactory report was designed and abstracted to include all participants' points of view. And finally, a document was prepared for the professional analysis.

\section{III.4. Gathering and analyzing the data}

In this study data, gathering and analyzing steps were as follows:

- The interview framework defined and, provided to the participants;

- All interviews recorded;

- Personal interviews were conducted separately after the participant's agreement and declaration of readiness;

- Each interview was formed into a text file (word doc); for the data preparation;

- An appropriate and expert report was prepared for each interview (to reduction);

- The main statements identified and labeled as an open code and, established an item pool to identify the influential variables; 
- The validation of coding process, expertise reports returned to participants and discussed about them. In addition to, sample interviews separated coded by 3 coder and agreement percentage measured (see table 2);

- Four clusters of open codes were categorized: Objective facts, Organizational Factors, Main Discourse of Community, and International Factors based on the Delphi technique to identifying triggering elements;

- Focused group interviews conducted in three rounds;

- The two main axes of the factor matrix were extracted for writing possible scenarios based on focused group interviews;

- Scenarios were developed and written; and

- Scenarios were validated (Table, 8).

\section{III.5. Validation}

To validation of findings in addition to discussions about participant's opinions, return expertise reports to interviewees and the constant presence of researchers in the field, two $\mathrm{Ph} . \mathrm{D}$. student in educational administration was asked to participate as a research collaborator (coder) in the research and code interviews number $4,6,8$, and 9 randomly. The measure of stability was obtained based on the following formula.

The stability of the coders using the above formula was $83 \%$. Given this formula, if the stability is greater than $60 \%$, coding is confirmed and it can be claimed that the stability of the interview is acceptable.

Table 2

Percentage of agreement within the subject

\begin{tabular}{|c|c|c|c|c|}
\hline Interview Title & Total & Agreements & Disagreements & Stability \\
\hline $\mathbf{4}$ & 41 & 35 & 6 & $85 \%$ \\
\hline 6 & 35 & 29 & 6 & $82 \%$ \\
\hline $\mathbf{8}$ & 32 & 28 & 4 & $87 \%$ \\
\hline 10 & 30 & 23 & 7 & $76 \%$ \\
\hline Total & 138 & 115 & 23 & $83 \%$ \\
\hline
\end{tabular}




\section{III.6. Ethical considerations}

- The aims of the study were explained to the participants.

- In order to record the interview sessions, the participants' permission was requested.

- In order to comply with the principles of confidentiality, the participants were assured that their statements would be published under a pseudonym or a code.

- In analyzing and reporting the data in the dissertation, pseudonyms will be used.

\section{Research findings}

\section{IV.1. Effective propellants of higher education in Khuzestan province}

What are the main factors affecting Khuzestan's Higher education to entrepreneurship and value creation in this province? And how could universities pay attention to these factors for a better future? To answer these key questions, in-depth interviews were conducted with 10 experts as described in Table 1. The interviews continued until theoretical saturation and 503 open codes were extracted. Open codes categorized into 105 main categories. The proponents of higher education affecting entrepreneurship and value creation in Khuzestan province (extracted categories) were not at the same level in terms of objectivity, subjectivity, and time dimension, therefore they were categorized into four levels of objective realities, organizational causes, community discourse, and international actions. The proportions of the university's role in entrepreneurship and value creation at the level of objective reality are presented in Table 2. Facts like graduation employment, establishing accreditation centres, documenting, setting up entrepreneurship counselling centres, inclining to measurable scientific activities such as paper publishing and writing with any level of academic acceptance, etc. are presented below. These are some existing facts in the world of higher education in Iran and Khuzestan province, not abstract facts that require a high degree of understanding and recognition.

Table 3 presents the organizational factors and causes. Organizational factors are largely dependent on intra-university mechanisms, and if higher education policymakers are willing to address them, they need to identify and modify them according to the local needs. For example, to have a strategic plan based on research needs and business creation in the region, higher education has to diversify funding mechanisms, 
document, and model the experiences of prominent local and national entrepreneurs, and continuing education and training of managers and faculty. The university is largely independent of accepting and operating certain activities. The creativity, ingenuity, and managerial capabilities of the province's higher education executives are very influential in this regard.

\section{Table 3}

Objective facts

\section{Propellants}

University graduate employment, structural centralization of higher education, extracurricular accreditation centres, requiring different sections of society to obtain scientific approvals for research activities and projects, establishment of entrepreneurship counselling centres, expanding tendency to quantitative research activities and quantifiable research such as articles and books, governmental organizations, degrees, accreditation, university accreditation and academic activities, attracting private-sector intellectual and financial partnerships, widespread and comprehensive engagement with local and regional communities, attention to industry, business and traditional work, setting up science parks technology, incubators, knowledge-based companies, doing university projects tailored to the needs of the community, industries and local and regional companies, supporting entrepreneurial activities, conducting collaborative research with industry and corporate owners, staffing with diverse specialties, interested students. Postgraduate research, higher education area of Khuzestan Province, higher education research centres in the fields of oil, gas, steel, petrochemical, electricity, water, aquaculture, new business and other entrepreneurship and value creation sections of Khuzestan Province, timely provision of resources.

Table 4 shows the proportions of the university's role in entrepreneurship and the value creation at the level of the general community discourse. These factors exist beyond the boundaries of universities and are applied in other organizations. Structural focus, strong dependence on the oil-based economy, difficulties in transferring decision-making power to the private sector, management stability, the constant shadow of international threats and sanctions, mutual trust, state-owned specialized companies, etc., are not limited to the higher education community, they, in fact, to a large extent, affect all the agencies and institutions of the country. Resolving problems at this level requires bargaining and the power to negotiate with transdisciplinary policymakers to formulate detailed future research plans for the entire community. 
Table 4

Organizational factors

\section{Propellants}

Quantitative expansion of universities and limited efforts to improve the quality of higher education, a centralized higher education program and a regional capability-based strategy, the need for higher education to attract funding in a variety of ways, the ability to respond rapidly to environmental change, modelling and documenting entrepreneurs' experiences and knowledge management, faculty members' ability to guide learning and conducting research, goal-oriented and program-oriented graduate student theses related to real community needs, building national and regional inter-university networking, fierce centralization in the education system of Iran, bureaucracy in governmental and non-governmental industries and organizations, stability of management in public and even private organizations, and attention to early-stage research affairs, the appropriateness of Khuzestan province's higher education academic model with native and local conditions, the optionality of research beyond university boundaries, creating an appropriate academic structure for technology creation and transferring it to the local and regional communities, establishing a communication network with university graduates, establishing a communication network with companies and government agencies to meet their needs, providing the platform for international dedicated revenue generation, mechanisms for receiving funds and educational services, ongoing university contact with institutes, industries and other sectors of society, designing courses tailored to the time and location of the private sector such as night and campus courses, recruiting technology faculty, student recruitment mechanisms, research fellowships, interdisciplinary research, the process of supporting innovative activities and new ideas, faculty members' desire for continuous communication with the environment and commercialization of knowledge, research and study culture, willingness to work in a team and team building, consumerist attitude toward higher education, mechanisms for restricting bureaucrats, an overly theoretical approach to the field academics, obstructive administrative rules, needless managers in higher education, abandoning or even shutting down projects and plans of former managers, restricting the intrinsic duties of the university to teaching and research, weak links between university departments and groups, managing university stability, introducing regional higher education opportunities to the community, applying and commercializing scientific findings, restrictive organizational structure, national, international and regional business market needs assessment, retraining system and increasing faculty members' skills, faculty motivation systems for doing entrepreneurial work. 


\section{Table 5}

Factors related to community discourse

\begin{tabular}{l} 
Propellants \\
\hline High university dependency on government funding - mainly public higher \\
education, community-university discourse, difficulties in delegating decision- \\
making power to individuals and organizations in the private sector, strong \\
structural centralization, indigenous industry and university mutual trust, the \\
constant shadow of threats and international economic and non-economic \\
sanctions, internationalization of industries and holdings, lack of need for \\
industry to conduct research, political and party affiliation with top university \\
executives, industrial dependence outside the country, managers' backlog \\
at the end of their management period, educating regional officials on \\
the status and mission of universities, the influence of political institutions \\
that are in conflict with academic independence, general higher education \\
policy making, informal and decisive communication networks in university- \\
community interactions, the community's short-term view of the university, \\
community and university ethics, university credibility with local and national \\
communities, community and university intertwining, community-university \\
common language, community-university mutual expectations, unequal \\
financial competition between the private and public sectors, banks and their \\
relationship with other investors in higher education university projects, a \\
politically and scientifically repressive atmosphere and the conservatism \\
of university faculty members, the degree of industry confidence in the \\
university, international interactions, the safe space of freedom of thought \\
and expression.
\end{tabular}

The factors and reasons that influence the success of higher education in fulfilling its fundamental mission are not limited to national and regional issues. Some of these factors are rooted in the structure of the international power and global power relations. The cases summarized in Table 5 are transnational factors that influence entrepreneurship success and value creation in Khuzestan higher education system. The burgeoning international changes in technology, international job seekers, international research projects, the global economy, and the fierce competition between societies to gain competitive advantages are beyond the scope and authority of higher education in the province and country, and the only solution to this problem is to identify the main concerns and intelligently deal with such phenomena.

What is presented in Table 6 are the integrated codes. For example, all the factors that somehow referred to the lack of a proper structure for provincial higher education policymaking are summarized in one objective factor: "the lack of Inter-province higher education policymaker". Other factors are mentioned in the table below. 
Table 6

Transnational factors

\section{Propellants}

The burgeoning international changes in technology and knowledge, the international move towards new technology-based businesses, transnational businesses, the needs across countries' geographical boundaries, fluctuations of the international economy, international applicants for higher education, opportunities to attract funds across geographical boundaries, suitability for transnational and transnational partnerships, international projects for higher education, the ability to use formal expertise in projects and even regional education, optimal use from international experiences, expanding the reach of digital technologies, membership in international unions and university meetings, engaging constructively with the international system.

Table 7

Summary of factors

\begin{tabular}{|c|c|c|c|}
\hline $\begin{array}{l}\text { Transnational } \\
\text { factors }\end{array}$ & $\begin{array}{l}\text { Community } \\
\text { dialogue }\end{array}$ & Organizational factors & Objective facts \\
\hline $\begin{array}{l}\text { International } \\
\text { productive } \\
\text { interactions, } \\
\text { changing } \\
\text { the nature } \\
\text { of business } \\
\text { infrastructures, } \\
\text { the formation } \\
\text { of a networked } \\
\text { society }\end{array}$ & $\begin{array}{l}\text { State-owned } \\
\text { and oil-based } \\
\text { economics, } \\
\text { weak mutual } \\
\text { trust between } \\
\text { the university } \\
\text { and society, } \\
\text { government } \\
\text { decision-making } \\
\text { power, private } \\
\text { sector margin } \\
\text { over the state, } \\
\text { instrumental } \\
\text { view of the } \\
\text { university, } \\
\text { high influence } \\
\text { and influence } \\
\text { on university } \\
\text { politics, } \\
\text { institutionalism } \\
\text { and neo- } \\
\text { institutionalism }\end{array}$ & $\begin{array}{l}\text { Concentrated } \\
\text { organizational } \\
\text { structure, ambiguous } \\
\text { university policies } \\
\text { and strategies, } \\
\text { national view of } \\
\text { provincial universities, } \\
\text { inefficiency of } \\
\text { faculty recruitment } \\
\text { indices, lack of } \\
\text { competition among } \\
\text { universities, instability } \\
\text { of management, } \\
\text { restrictive } \\
\text { intra-university } \\
\text { mechanisms, lack } \\
\text { of inter-university } \\
\text { communication } \\
\text { networks, severe } \\
\text { dependence on } \\
\text { government } \\
\text { resources, lack } \\
\text { of delegation of } \\
\text { responsibilities } \\
\text { commensurate with } \\
\text { responsibilities }\end{array}$ & $\begin{array}{l}\text { Lack of trusted } \\
\text { institution } \\
\text { of higher } \\
\text { education } \\
\text { policy making } \\
\text { in the province, } \\
\text { lack of } \\
\text { effective and } \\
\text { productive } \\
\text { communication } \\
\text { between } \\
\text { university, } \\
\text { industry and } \\
\text { society, lack } \\
\text { of university } \\
\text { funding }\end{array}$ \\
\hline
\end{tabular}




\section{IV.2. Scenario logic}

Scenario-based research requires identifying key axes and loading other factors onto them. These axes outline the general direction of the problems at hand. The results of the analysis showed that two key factors affect the future of higher education in Khuzestan province in the 2022 horizon to entrepreneurship and value creation. The first one is the society's expectations of higher education and the second is, the oil-based state economy. According to these two key factors, alternative scenarios for higher education in Khuzestan province are hypothesized. Academic models emerging from the intersection of the two axes are strongly influenced by the wide range of the country's economic situation (government economy based on oil exports and sale of other raw materials to a competitive market-based economy) and, the range of community expectations (university as an independent entity, which is responsible for responding to the demands and preferences of the community, rather than the university as a government-affiliated organization indulged in intra-university preferences. Accordingly, four alternatives for the future of Khuzestan higher education in horizon 2022 are proposed in Figure 2.

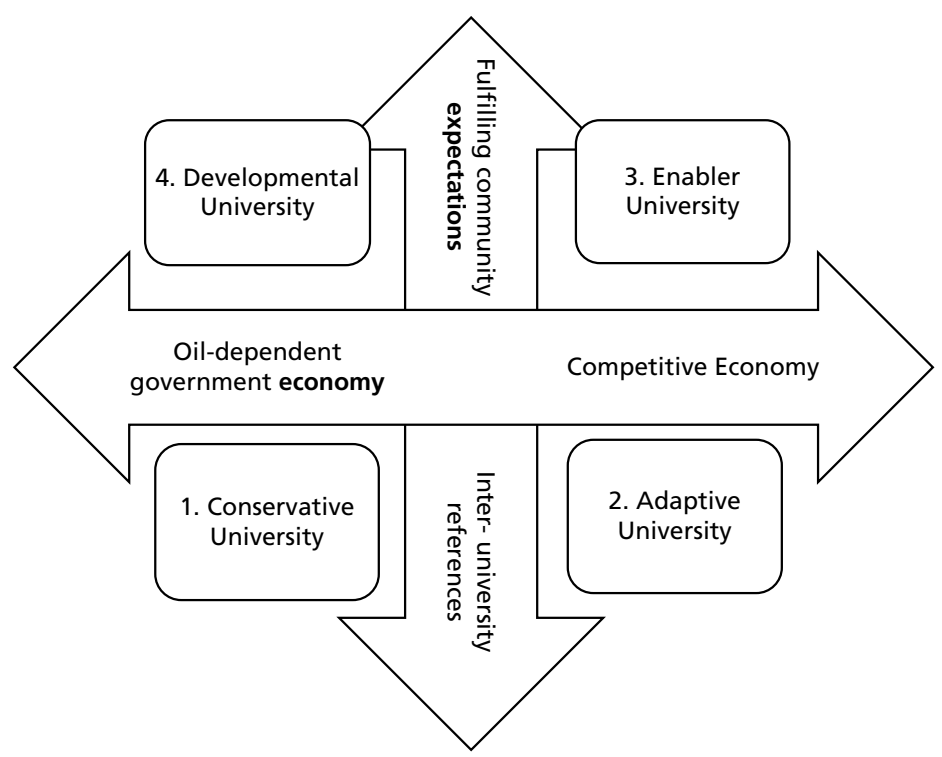

Figure 2

Four alternative scenarios for higher education in Khuzestan province 
1) Conservative university: The conservative university represents a model in which the university and the intra-university complex are heavily dependent on state and oil economics. Communication networks between the community and the university are very weak and the academic system prefers to be confined to its basic research cocoon. In many cases, the fear of losing a job convinces managers and faculty members to show approval to government. On the other hand, by interfering with all intra-university processes, the government limits the relative independence of the university and asks the university to do what it desires to. The conservative university has an intra-organizational approach and behaves in a way that might be difficult for others, especially for the main funder. The social responsibility of this academic model is limited to the accountability of individuals and organizations to the superiors, and the local community has a minor role in its management and policymaking. The university does not feel responsible for graduates and concepts like freedom of thought and expression, university independence, merit-based management, meeting local community expectations, liberating from structural and administrative constraints, and attracting high-end people become luxurious election slogans. The conservative university is not willing to participate in collaborative research projects outside the university, especially in situations where it is likely to endanger its prestige. Such a university, of course, is capable of maintaining its position and can continue to leverage public funding every day. The university relates the failure to meet the expectations of the society to the difference between theoretical foundations and social realities and, therefore, removes the guilt of failure to meet the expectations, from its record. Because of being dependent on the government in many respects and competing for resources and facilities, the university does not pay due attention to the regional and even international needs, and its interdependence to the external environment is clearly obvious. Consequently, university presidents are not the ultimate decision-makers in the face of the external environment. The concern for survival and persistence among the managers of these universities is in the management positions and does not threaten their financial risk.

2) Adaptive university: The comparative university consists of the intersection of a competitive economy and attention to intrauniversity preferences. In this scenario, the external environment 
of the university includes the social environment and the organizational environment. The university is part of an organizational environment before it is part of a larger and wider social environment. Therefore, the preferences of the university are focused on the intra-university environment. The social environment is complex, unpredictable, and chaotic, and undergoes alterations such as changes in technology, economics, ecology, and social changes such as globalization. Universities cannot be indifferent to the changes in the social environment, especially economic changes; they cannot be a mere subsidiary of these comprehensive changes. Thus, they prefer to find new tools to adapt to these developments. These tools include revenue diversification, emphasis on entrepreneurship and value creation, corporate governance, and joint ventures with a competitive market. The organizational environment of this academic model is a function of their social environment. This university model proposes that, to meet the demands of the external environment, enhance the quality of education, streamline university programs, increase access to higher education and lower the costs of higher education, changes have to be made in the quality of services provided by the higher education system. In this model, compatibility means reducing the imbalance between the external environment and the university. The university adaptation to the external environment is created through two categories of structural and process factors. Structural factors include entrepreneurial culture, diverse capabilities, and a defined mission statement for the university. Process factors include professional management, corporate governance, and committed leadership. Managers need to re-consider their missions, change structures and processes, and encouraging strategies must be employed, department leaders should be more involved and more prepared in the faculty, and they have to think outside the box using entrepreneurial planning.

3) Enabler university: The enabling university is an ideal university that is unlikely to reach the horizon of 2022 in Khuzestan higher education. Continuing to address community expectations and intra-university preferences, this model of higher education oversees a modern university with diverse funding sources. It has no financial or managerial affiliation with any individual or organization and is interconnected with the local community and business network far and wide. Based on its intra-system capabilities, 
it has been able to persist and operate in a competitive national and international environment. It can, therefore, benefit from the efforts and stakeholders' engagement to create a competitive advantage, while building productive and targeted interactions with the national and international systems, empowering local capacities internationally. Professional independence and academic freedom are available at the university. Since they are looking for their future talents at such a university, the university does not attempt to attract input; in other words, the best students and professors are seeking to work in such an environment. Biomedical, collaborative mobility, trust in the administrative and structural processes at such a university are evident, and the organizational structure of the university has the potential to be highly resilient to change. The needs of local, national, and international communities take precedence over intra-university desires and preferences. Planning to achieve this academic model based on the components of higher education in Khuzestan province over a defined timeframe seems to be largely hypothetical. This is because moving away from dependence on state funding and directly shifting towards addressing the needs of the community is time-consuming and requires long-term planning.

4) Developmental university: The developmental university formed from the cross-section of the realization of society's expectations and the state economy. In this scenario, it is considered impossible independence on the oil economy in the short and medium-term. The orientation of this university model will be towards fulfilling society's expectations by using state funding in a limited timeframe. In this case, the development infrastructures are identified and a set of mechanisms are used to guide government financial flow in support of local community expectations. Intra-university competencies, granted by government funding, serve to meet the expectations of the community, in which negotiation plays a crucial role. Nowadays, the bargaining chip of universities is not merely to conduct research and produce knowledge, but to convert these findings into products and transfer the knowledge and technologies in accordance with the expectations and needs of the society. In this scenario, then, intra-university preferences might be overlooked, so the university would work to meet the needs and expectations of the local community via the production of knowledge and its transfer into products. 


\section{IV.3. Scenario validation}

The validity of the scenarios was evaluated and presented in table 7 based on four main criteria: Feasibility, Utility, Internal Consistency, and Differentiation. The scenario feasibility indicates the feasibility of its implementation within a defined timeframe. Utility refers to the usefulness of the scenario for the accomplishment of a series of set goals. Internal consistency refers to the content consistency of the scenarios and the differentiation examines the acceptable variations between alternative scenarios.

Table 8

Experts' validation of scenarios

\begin{tabular}{|c|c|c|c|l|}
\hline $\begin{array}{c}\text { Developmental } \\
\text { University }\end{array}$ & $\begin{array}{c}\text { Enabler } \\
\text { University }\end{array}$ & $\begin{array}{c}\text { Adaptive } \\
\text { University }\end{array}$ & $\begin{array}{c}\text { Conservative } \\
\text { University }\end{array}$ & Criteria \\
\hline 4 & 1.8 & 2.6 & 4 & Possibility \\
\hline 4 & 4 & 3.2 & 1.2 & Usefulness \\
\hline 3.6 & 3.4 & 3.6 & 3.6 & Internal Adaptive \\
\hline 3.6 & 3.6 & 3.2 & 3.2 & Differentiation \\
\hline 15.2 & 12.8 & 12.6 & 12 & Sum \\
\hline
\end{tabular}

The table above shows the average score of each scenario based on the experts' opinions. The feasibility scores for the compatible university and the enabling university up to 2022 were estimated to be 1.8 and 2.6, respectively, for Khuzestan province. These values indicate that the creation of these academic models in a short time-span is out of reach, and planning to achieve and establish such universities, especially the empowering university, is out of the question. In contrast, both the conservative university and the developmental university models have achieved the highest possible score (4) and are accessible. The common grounds of the empowering and the developmental universities is their usefulness, for which both models gained a score of 4 . However, according to the experts, the conservative university with a score of 1.2 is not ready enough to play an active role in entrepreneurship and value creation in Khuzestan province. An average score higher than 3.5 indicates that the experts believe all the four alternative scenarios have acceptable internal consistency and that their underlying logic is reasonable. In terms of differentiation, a mean score of 3.4 indicates that all the four scenarios are 
significantly different. Overall, according to the intellectuals and experts, the preferred scenario of the present research is the development-oriented university, as its total score, 15.2, is higher than the other models. Executive recommendations will be given accordingly. ${ }^{66}$

\section{IV.4. Preferred scenario: developmental university}

Current universities, considered as conservative universities by the participants of the study, attempt to avoid comparisons with other universities and similar organizations at national and international levels because of the significant grants they receive from the sale of oil and other raw materials. To withdraw from the competition, such universities prefer to rely on factors that are not much decisive in a performance-based world, but which facilitate and ensure their survival. For instance, the number of students, professors, and staff which, in the functionalism approach are very important, have been replaced by more significant factors such as scientific outputs, global credibility, and the extent to which regional and national needs are met. Despite having national financial resources, current conservative universities are reluctant to respond to local and regional demands that do not comply with intra-university preferences.

The preferred scenario of the research for the higher education of Khuzestan province on the horizon of 2022 is the developmental university. Regarding the developmental university, it is believed that the role of universities in the age of globalization has changed and they are responsible for the society, its socio-economic development, and the educational market. The fundamental developments of our era occur in universities.$^{67}$ In higher education for the 21 st-century, UNESCO describes the university as "A place where entrepreneurial skills of graduates to create a job will be enhanced" ${ }^{68}$ According to this definition, in addition to the functions of education and research, the university has another important duty; "training people and

${ }^{66}$ Golam Ali Montazer, and Negar Falahati, "Scenario writing for the future of Iranian higher education and the application of information technology in it," Journal of Science and Technology Policy (JSTP) 7 no 1 (2015): 47-68. http://jstp.nrisp.ac.ir/article_12911_en.html.

${ }^{67}$ Seyyed Ali Naghavi, and Hamed Falah, 2012, "Investigating the Relationship between University and Industry through an Entrepreneurial Approach, Paper presented at the, Babolsar: Taro," National Conference on Entrepreneurship and Knowledge-Based Business Management, Babolsar: North Tarod Research Institute

${ }_{68}$ Mohammad Azizi, and Ehsan Shafizadeh, 2013, Entrepreneurial University: Necessity, Features, and Requirements, (Tehran: Islamic Parliament Research Centre Of IRAN, 2013), https://rc.majlis.ir/fa/mrc_report/show/863422 
institutes that they are a job creator". We must redefine the university graduates; an entrepreneur university graduate is a legal or natural person who encourages innovation in his or her environment and uses the knowledge alongside the experimental research to create innovation. We must re-define a university graduate; an entrepreneur university graduate is a legal or natural person who innovates in his or her environment and uses knowledge alongside applied research to create innovation. ${ }^{69}$ According to UNESCO, the essential capabilities for sustainable development are (1) Learning how to learn, (2) Learning to live with others, (3) Learning to practice, (4) Learning to live. Three main components of learning how to practice are: acquiring relevant job skills, learning social skills, and leading the way in implementing changes. These basics and their components are the required qualities to be considered an entrepreneur, therefore, they should be taught in higher education institutions. ${ }^{70}$ In a humanistic approach to education, it is claimed that the purpose of learning is "sustaining and enhancing the dignity, capacity and welfare of the human person in relation to others, and to nature, should be the fundamental purpose of education in the twenty-first century. The humanistic values that should be the foundations and purpose of education include respect for life and human dignity, equal rights and social justice, cultural and social diversity, and a sense of human solidarity and shared responsibility for our common future". ${ }^{71}$ A newer construct for explaining the learning process and goal is lifelong learning. In UN definition, Lifelong learning is the "ongoing, voluntary, and self-motivated pursuit of knowledge for either personal or professional reasons. Therefore, it not only enhances social inclusion, active citizenship, and personal development, but also selfsustainability, as well as competitiveness and employability". ${ }^{72}$

The developmental university is not too dreamy in diversifying university funding. This academic model encompasses the facts, and does not lay expectations on the university to grant itself financially based on free-market

69 Seyyed Hosein Mousavi, Ebrahim Salehi Omran, Maghsoud Ferasatkhah, and Jafar Towfiqi, "Presenting the development model of Entrepreneur University in Iran," Quarterly Journal of Engineering Education in Iran 19 no 76 (2017): 1-28. Doi:10.22047/ IJEE.2018. 98838.1481.

${ }^{70}$ UNESCO, 2004, Higher education in Europe: Thematic reflections on higher education, $\mathrm{Vol}, 29$.

${ }^{71}$ UNESCO, 2015, Rethinking Education towards a global common good, United Nations Educational, Scientific, and Cultural Organization, http://www.unesco.org/new/ fileadmin/MULTIMEDIA/FIELD/Cairo/RethinkingEducation.pdf.

${ }^{72}$ Bruno Tindemans, and Vickie Dekocker, "The Learning Society," Accessed 18 September (2020), https://www.oecd.org/publications/oecd-skills-strategy-flanders9789264309791-en.htm 
mechanisms. Therefore, in this model, a gradual change from state financing to self-financing based on a free and competitive economy is expected. But it's a long-term, far-reaching goal that one can imagine on a farther horizon. The developmental university does not want to succumb to the greatest and most dangerous structural weakness of the society ${ }^{73}$ because it understands that relying on the state budget makes them vulnerable and overshadows their independence, academic freedom, and the role of enlightenment. However, in the short term, the developmental university agrees that the solution to this problem is to use government funds though not as a permanent solution for all times.

On the other hand, the development-oriented university serves the realization of the society's expectations. The community's trust in universities to play a role in the realization of the development emphasizes the mission of community service and their responsibility to embrace the needs of the society which is consistent with the philosophy of public education in the higher education system. According to this philosophy, knowledge is a resource and tool that aims to nurture humanity as a whole, and higher education emphasizes the cultivation of the self, in addition to the cultivation of reason and wisdom, to nurture conscious citizenship in all conditions. Interdisciplinary courses emphasize public education because one is placed in a network of social, ethical, historical, sociological values, and must be equipped with special abilities and aspects to solve their problems and pay attention to different phenomena. Public education emphasizes communication skills, critical thinking, problem-solving skills, aesthetic understanding, the ability to make ethical decisions, and an interest in lifelong learning for university graduates. Hence, the emphasis on education for sustainable development is, in fact, to re-capture universities' attention to the provision of public education and their importance in realizing development.

At the developmental university, reviewing perspectives, policies, structures, educational processes, teaching methods, educational contents are essential to change the way of thinking and lifestyles, nurture capabilities of future generations, and satisfy the needs of the society. Paying attention to formal, informal and tacit instructions, closely linking university educational, research and social services programs, community-based disciplinary studies, and developing the incentive systems necessary for university faculty to engage in sustainable development, preservation and revitalizing the environment, revising the educational content of various academic

${ }^{73}$ Maghsoud Ferasatkhah, University History in Iran (Tehran: Institute for Cultural and Social Affairs, 2017) 
disciplines, using effective teaching methods, and revising learning assessment practices will play critical roles in building the required development capabilities. ${ }^{74}$ The followings are practical suggestions help achieving a developmental university in Khuzestan province:

1) Establishment of provincial policy institution for higher education in Khuzestan Province

2) The use of higher education intellectuals and local managers in policymaking

3) Creating and establishing a new business school/college and university

4) Policymaking for university-wide engagement with industry and society

5) Establishment of joint growth centers

6) Creating interdisciplinary disciplines at active universities

7) Establishment of a local/regional labor market university network

8) Establishment of a regional university network to intelligently coordinate students

9) Policymaking for minor reforms in the field of academic education and research in the province

10) Policymaking to support the academic system of the province

\section{Conclusion}

According to Estrin, et al, human capital, ability, and skill are the essential elements needed to acquire entrepreneurship and value creation for the society. ${ }^{75}$ There are research findings which assert these claims, for instance Castro et al, showed that the higher education has an important role in creating synergies between actors of the innovative ecosystem who strengthen the ties of social and economic growth ${ }^{76}$ and Jiao discusses that social and institutional environmental factors promote social entrepreneurship activities which stimulate social improvement ${ }^{77}$ Therefore, the development of higher education is considered an almost unconditional strategy to tackle

${ }^{74}$ Hamid Reza Arasteh, and Elham Amiri, "The Role of Universities in Sustainable Development Education.” Journal of Transplanting Science, 2 no 2 (2012): 29-36.

75 Saul Estrin, Tomasz Mickiewicz, and Stephan Ute, "Human capital in social and commercial entrepreneurship," Journal of Business Venturing no 31 (2016): 449-467. Doi. org/10.1016/j.jbusvent.2016.05.003.

${ }^{76}$ May Portuguez Castro, Carlos Ross Scheede, and Marcela Georgina Gómez Zermeno, "The Impact of Higher Education on Entrepreneurship, and the Innovation Ecosystem,"

${ }^{77}$ Hao Jiao, "A conceptual model for social entrepreneurship directed toward social impact on society. “ 
different types of social, political, economic, and geographical inequalities in low-income and less-developed countries. ${ }^{78}$ According to the scholars, the university could participate in local and global growth, through providing educational services to the community. This goal is fulfilled via proper management and proportional accountability to the community demands. In short, the social responsibility of the university is to achieve a sustainable development of the society and the effort to redirect the higher education goals to meet the social goals, insights, and global values. ${ }^{79}$

The concept of entrepreneurship development, focusing on universities and aimed at spreading academic knowledge and transferring knowledge to companies and organizations, leads to the social and economic development of societies. The first wave of this approach focused on prestigious universities in the United States such as Stanford and MIT. The second wave of this approach occurred in Western Europe. With the emergence of universities that have become entrepreneurial institutions, they aimed to support academic entrepreneurs in the emerging economies. The third wave, or the current ongoing process, relates to the policies and structures that government officials have embedded in their strategic plans to develop and promote entrepreneurship. But it is not clear which policies and structures can help develop entrepreneurship more effectively. ${ }^{80}$ Nevertheless, what most scholars agree upon is the role of universities and higher education institutions in promoting entrepreneurship and value creation. In this process, the following issues can be considered, particularly for Khuzestan province:

Higher education to influence the economy of the region must inevitably move to the third wave of the effective inter-provincial policymaking. As such, one can look at the infrastructure of the region's indigenous culture and its potential for entrepreneurship and value creation, as well as for economic and social development. According to Wilson scholarly research in urban and regional economic development has been heading unwittingly toward a postmodern embrace of locality ${ }^{81}$ The second issue is the type of governance

${ }^{78}$ Simon Datzberger, "Peacebuilding through non-formal education programs: a case study from Karamoja, Uganda.” International Peacekeeping 24 no 2(2017): 326-349. doi:10.1 080/13533312.2016.1214073.

79 Jose L V Burguete, Carlota Lopez, and Ana Lanero, “ Are students aware of university social responsibility? Some insights from a survey in a Spanish university," International Review on Public and Non-profit Marketing no 11 (2014): 195-208. doi:10.1007/s 12208-014-0114-3.

${ }^{80}$ Gustavo Dalmarco, Willem Hulsink, and Guilherme Blois, "Creating entrepreneurial universities in an emerging economy: Evidence from Brazil." Technological Forecasting and Social Change, Elsevier no 135 (2018): 99-111. doi:10.1016/j.techfore.2018.04.015.

${ }^{81}$ Patricia Wilson, "Embracing Locality in Local Economic Development," Urban Studies, 32 no 4-5 (1995): 645-658. Doi.org/10.1080/00420989550012816. 
in higher education in the country, a serious challenge that is the transfer of decision-making power to inter-provincial agents. Having a developmental university requires a clear vision, enable and enabler leaders and educated work force. ${ }^{82}$ Did local universities have these requirements? To what extent are administrators and centralized systems in the relevant departments willing to delegate part or all of their decision-making power to interprovincial actors? For a decentralized higher education, decentralization must be accepted and inter-provincial capacities must be believed. The rulers of higher education and even higher levels of government should admit that the era of decentralization of higher education has arrived much earlier in modern countries. In this case, another challenging issue of future higher education is "Revenue will go way down, and costs way up" 83 in addition, those who fund higher education try to contribute to its government. The third issue that is less addressed and is relatively overlooked is the discussion of the environmental impacts and environmental ecosystem planning for higher education activities. There is a wide gap between the traditional and industrial sectors of employment in the province. Is the university going to take the entrepreneurial approach off the traditional market and modernize it by providing economic and social development? Why has not the transfer of knowledge from different academic centers helped much in the industry, business, and economics Peters, et al. ${ }^{84}$ and how can it be tailored to the regional benefits of a good prospect for creating and developing entrepreneurship and value? Creating an approach that addresses traditional and modern competencies simultaneously is a crucial issue for future higher education. The last issue is, financing entrepreneurship programs and value creation. In other words, the most important policy is the financial orientation that can lead to the success or failure of a program. Even the best policies, if not funded, would not contribute to economic and social development and will remain attractive on the board of directors. Futurism is inherently difficult. Uncertain futures, unknown factors, and sudden changes can make the results of future studies unreliable. Also, the university presidents and

${ }^{82}$ Hamid Farhadi Rad, Sakineh Shahi, and Forogh Tahmasebi, "An investigation into the requirements, and circumstances of decentralization in Ahvaz education: viewpoint, leadership and human resource

${ }^{83}$ Johan Kroger, Leadership in Higher education, Accessed may 26. https://www. insidehighered.com/blogs/leadership-higher-education/10-predictions-higher-education\% E2\% $80 \% 99$ s-future.

${ }^{84}$ Peters, Guy, Giliberto Capano, Michael Howlett, Ishani Mukherjee, Meng-Hsuan Chou, and Pauline Ravinet, Designing for Policy Effectiveness: Defining and Understanding a Concept, (Cambridge University Press, 2018), Doi:10.1017/9781108555081. 
higher education experts do not have the same viewpoints about the future of higher education, so maybe comparative studies are necessary in this regard. As a matter of fact, the variety of social sections and university majors adds to the complexity of this line of research and can be considered as the limitations of the present study. Finally, it is recommended that future researchers focus on one specific area of investigation, e.g., engineering student's entrepreneurship.

In general, it should be mentioned that, in order to have an entrepreneur and valuable university in Khuzestan, it is necessary to attend to the fundamental developments of Higher Education and young generations in universities. According to the related literature, universities today are different from the more traditional ones whose emphases were on creating and extending knowledge (Engwall 2020). In late 20th century, while accepting the traditional role of universities and referring to the world economy as knowledge-based economy, Sir Ron Dearing introduced universities as the key elements in socioeconomic development, ensuring competitive advantage through human resource development; he acknowledged the crucial role of market forces and the facilitative role of government in achieving to the abovementioned goals ${ }^{85}$ Under such a vista, values such as participation in economic modernization, public welfare, workforce preparation, and technological values find significance alongside academic values. In fact, according to the present mindset, university is at the service of knowledgebased economy. The fourth generation universities, which are somehow under the effects of the fourth industrial revolution too, are not satisfied with the triple participation of government, university, and industry, ${ }^{86}$ and go beyond the discourse of knowledge-based economy. In other words, a fourth generation university that is a society engaged organization values knowledgebased economy when it is at the service of the human being and the society (Nabipour 2020). According to the model proposed by Carayannis and Campbell, ${ }^{87}$ socioeconomic development is not possible if it is not sensitive to environmental contexts, even if it is at the service of human and society.

${ }^{85}$ Bell Les, Mike Neary, and Howard Stevenson, “The Future of higher education: policy, pedagogy, and student experiences".

${ }^{86}$ Henry Etzkowitz, and Loet Leydesdorff, "The transformation of university-industrygovernment relations," Electronic journal of Sociology 5 no 4 (2001): 101-117.

${ }^{87}$ Elias G Carayannis, and David F.J Campbell, "Triple Helix, Quadruple Helix And Quintuple Helix And How Do Knowledge, Innovation And The Environment Relate To Each Other?: A Proposed Framework For A Trans-Disciplinary Analysis Of Sustainable Development And Social Ecology," International Journal of Social Ecology and Sustainable Development 1 no 1 (2010): 41-69, doi:10.4018/jsesd.2010010105. 
Therefore, the fifth-generation university requires the government, university, industry, and society to be in positive and constructive cooperation with the natural environment. These theoretical studies show that the higher education road map in Khuzestan should be developed based on the principles of fourth and fifth universities with the human, society, and environment at the heart. It should, however, be mentioned that, although having a university which can serve knowledge-based economy purposes is presently an ideal type of university in the province, it seems that, for long-term Higher Education planning in Khuzestan, values of fifth generation universities should be simultaneously taken into consideration.

\section{Bibliography}

Akhilesh, K.B. Co-Creation and Learning Concepts and Cases. SpringerBriefs in Business, 2017.

Aldianto, Leo, Grisna Anggadwita, and Aang Noviyana Umbara. "Entrepreneurship education program as value creation: Empirical findings of universities in Bandung, Indonesia.” Journal of Science and Technology Policy Management 9 , no. 3 (2018): 296-309.

Amini, Mohammad Taghi, Mohammad mahdi Parhizgar, Mehran Rezvani, and Saeed Farjam. "Designing a Conceptual Model of Value Creating Entrepreneurship (Fourth Wave)." Modern Marketing Research 5, no. 1 (2015): 19-30.

Amiron, Evarina , Azlan Abdul Latib, and Kamalularifin Subari. "Industry Revolution 4.0 Skills and Enablers in Technical and Vocational Education and Training Curriculum." International Journal of Recent Technology and Engineering (IJRTE) 8, no. 1 (2019): 485-492.

Arasteh, Hamid Reza, and Elham Amiri. "The Role of Universities in Sustainable Development Education." Journal of Transplanting Science (Nasha-e-Elm) 2, no. 2 (2012): 29-36.

Azizi, Mohammad. "Analytical-Comparative Study of the Performance of Top Entrepreneurship Centers of American Universities and Entrepreneurship Centers of Selected Iranian Universities." Journal of Innovation and Value Creation 4, no. 8 (2016): 21-32.

Azizi, Mohammad, and Ehsan Shafizadeh. Entrepreneurial University: Necessity, Features and Requirements. Tehran: Islamic Parliament Research Center Of The Islamic Republic Of IRAN, 2013,3.

Azmi, A Janwa, Yusri Kamin , M Khair Noordin , and A Nabil Nasir . "Department of Technical and Engineering Education, Faculty of Education, Universiti Teknologi Malaysia, 81310 UTM Skudai, Johor Bahru, Johor, Malaysia." International Journal of Engineering \& Technology 7, no. 28 (2018): 267-272.

Barabadi, Abolghasem, malek Mohammadi, and Ali Asadi. "Educational, social and cultural barriers to employment of agricultural graduates." Economics, labor and society no.109(2009): 92-100. 
Bell, Les, Mike Neary, and Howard Stevenson. The Future of higher education: policy, pedagogy and student experiences. Translated by Jalil Karimi, \& Peyman Karimi. 2009.

Brieger, Steven, Anne Baro, Giuseppe Criaco, and Siri Terjesen. "Entrepreneurs' age, institutions, and social value creation goals: A multi-country study." Small Bus Econ, 2020.

Burguete, Jose L V, Carlota Lopez A, and Ana Lanero. "Are students aware of university social responsibility? Some insights from a survey in a Spanish university." International Review on Public and Nonprofit Marketing, no. 11 (2014): 195-208.

Carayannis, Elias G, and David F.J Campbell. "Triple Helix, Quadruple Helix And Quintuple Helix And How Do Knowledge, Innovation And The Environment Relate To Each Other?: A Proposed Framework For A Trans-Disciplinary Analysis Of Sustainable Development And Social Ecology." International Journal of Social Ecology and Sustainable Development 1, no. 1 (2010).

Castro , May Portuguez , Carlos Ross Scheede , and Marcela Georgina Gómez Zermeno. "The Impact of Higher Education on Entrepreneurship and the Innovation Ecosystem: A Case Study in Mexico." Sustainability 11, no. 20 (2019): 1-17.

Chemi, Tatiana, and Lone Krogh. Co-creation in Higher Education: Students and Educators Preparing Creatively and Collaboratively to the Challenge of the Future. Vol. 6. Aalborg : Aalborg University, 2017.

Chen, Shu-Hsiang, Jaitip Nasongkhla, and Ana Donaldson. "University Social Responsibility (USR): Identifying an Ethical Foundation within Higher Education Institutions." The Turkish Online Journal of Educational Technology 14, no. 4 (2015): 164-172.

Clark, Burton. "The Entrepreneurial University: New Foundations for Collegiality, Autonomy, and Achievement." Higher Education Management 13, no. 2 (2004): 23-36.

Dalmarco, Gustavo, Willem Hulsink, and Guilherme Blois. "Creating entrepreneurial universities in an emerging economy: Evidence from Brazil." Technological Forecasting and Social Change, Elsevier 135, no. C (2018): 99-111.

Datzberger, Simone. "Peacebuilding through non-formal education programs: a case study from Karamoja, Uganda.” International Peacekeeping 24, no. 2 (2017): 326-349.

Emadzadeh, Mostafa. Economics of Education. 30. Esfahan: Jahad Daneshgahi, 2016. Engwall , Lars. Missions of Universities Past, Present, Future. Vol. 55. Oslo, Norway: Springer, 2020.

Estrin, Saul, Tomasz Mickiewicz, and Stephan Ute. "Human capital in social and commercial entrepreneurship.” Journal of Business Venturing 31 (2016): 449-467.

Etzkowitz, Henry, and Loet Leydesdorff. "The transformation of university-industrygovernment relations.” Electronic journal of Sociology 5 , no. 4 (2001): 101-117.

Fahey, Liam, and Robert M Randall. Learning from the Future: Competitive Foresight Scenarios. Wiley, 1998. 
Farhadi rad, Hamid, Abdollah Parsa, and Elaheh Rajabi. "Employability of Iranian Engineering graduates: Influential factors, consequences and strategies." The Journal of Teaching and Learning for Graduate Employability (Deakin University of Australia) 11, no. 1 (2020): 110-130.

Farhadi Rad, Hamid, Sakineh Shahi, and Forogh Tahmasebi. "An investigation into the requirements and circumstances of decentralization in Ahvaz education: viewpoint, leadership and human resource." Journal of new approaches in educational administration 10, no. 38 (2019): 57-76.

Ferasatkhah, Maghsoud. University History in Iran. Tehran, Iran: . Tehran: Institute for Cultural and Social Affairs of the Ministry of Science, Research and Technology, 2017.

Fereidouni, Somayeh. Social implications for the quantitative development of higher education; grounded Theory. Tehran: Institution for research and planning in Higher education, 2018.

Feyz, Mehdi. Identifying the desired professional qualifications of engineering graduates in iran:sharif university of technology graduates. shahid beheshti university, 2010.

Galvin, Robert. “Science Roadmaps.” Science 280, no. 5365 (1998): 803-803.

Ghalandari, Mohammad Ali. Entrepreneurship University indicators (Case Study): Shahid Chamran University Ahvaz, Iran. Master Thesis, Education, Ahvaz: Shahid Chamran University Of Ahvaz, 2010.

Ghanbari, Ali. University in regional context: Isfahan university. Tehran: Social and cultural Research center, 2017.

Ghaneirad, Mohammad Amin. "Uneven development of higher education: Unemployment of graduates and migration." Social Welfare Quarterly 4, no. 15 (2005).

Gibb, Allan, Gay Haskins, and Ian Robertson. Leading the entrepreneurial university: Meeting the entrepreneurial development needs of higher education institutions. Said Business School, University of Oxford, 2009, 1-44.

Hajipoor, Ebrahim, Lotfollah Frouzandeh, Hasan Danaee Fard, and Asghar Fani. "Designing a Pathological Pattern for Public Policy Implementation in Iran." Military Management Quarterly 15, no. 28 (2015): 1-23.

Halberstadt, Jantje , Jana-Michaela Timm, Sascha Kraus, and Katherine Gundolf. "Skills and knowledge management in higher education: how service learning can contribute to social entrepreneurial competence development." Journal of Knowledge Management 23, no. 10 (2019): 1925-1948.

Hasani, Sayed Ghasem. University and Regional Development: Mazandaran University. Tehran: Institute for Cultural and Social Studies, Ministry of Science and Technology., 2017.

Herman, Jerry J, and Janice L Herman. Making Change Happen: Practical Planning for School Leaders (First ed.). California: Corwin Press, 1993.

Hoseini Moghadam, Mohammad. Iranaian University in the international Environment: Internationalization of Iranian Higher education and future of university in Iran. Tehran: Research Center for Social-Cultural Studies, 2017. 
Institute for Research and planning in Higher Education. 2019. https://irphe.ac.ir/ content/1921/.

Jiao, Hao. "A conceptual model for social entrepreneurship directed toward social impact on society." Social Enterprise Journal 7, no. 2 (2011): 130-149.

Josvisin, Palmyra, Trans McLaughlin, David Bridge, Roberta Josvisius, and Julant Stankovisius. Higher Education and National Development: Universities and transitional societies. Translated by Reza Simbar. Tehran: Cultural and Social Studies Research Institute, 2011.

Keramat Zadeh, Abdolmajid . "The Role of Cognitive Metaphors in FS: An Analysis of Sohail Inayatallh's Viewpoints." Journal of Iran Futures Studies 1, no. 1 (2016): 15-32.

Khadem Alizadeh, Amir, Hamideh Amadeh, and Mahboobeh Baghalian. "The imoact of economic sanctions on employment in Iran." Economic Strategy (Strategic Research Institute) 11, no. 3 (2014): 79-104.

Khosravi, Mahboobeh, Kourosh Fathi Vajavgah, Hasan Maleki, and Daryoush Nouroozi. "Investigating the Adoption of Curriculum Innovations in Higher Education System (Case Study: Curriculum Revision Code of Iranian Universities)." Journal of Educational Psychology 9, no. 27 (2013): 135-166.

Kostoff, Ronald, and Robert Schaller. "Science and technology roadmaps." IEEE Transactions on Engineering Management 48, no. 2 (2001): 132-143.

Kroger, John. LEADERSHIP IN HIGHER EDUCATION. may 26, 2020. https:// www.insidehighered.com/blogs/leadership-higher-education/10-predictionshigher-education $\%$ E2\%80\%99s-future.

Maknoun, Reza. "Country higher education employment and development strategy." Proceedings of the Strategic Congress of Scientific Development of Iran, Ministry of Science, Research and Technology. ran science promotion headquarters 1400, 2001.

Memarian, Hossein. "Mechanism for evaluating engineering education programs: from ideal to reality." Fifth Conference "Quality Assessment in the University System” - University of Tehran - Campus of Technical Colleges. Tehran: University of Tehran, 2011.

Moein, Mostafa. Higher Education Policy and Development. Tehran: Institute for Cultural and Social Studies, Ministry of Science and Technology., 2018.

Mohammad Shafi, Mahboubeh, Mohammad Reza Neyestany, Ebrahim Jafar, and Vida Taghvaei. "Evaluating the Quality of the Curriculum in Skills Training." New Educational Approaches 15, no. 31 (2020): 70-102.

Momeni Mahmoei,Hossein, Ali SHariatmadari, and Ezatullah Naderi. "Competencybased curriculum in higher education." quarterly Educational, 2008: 5(17), 129-156.

Montazer, Gholam Ali, and Negar Falahati. "Scenario writing for the future of Iranian higher education and the application of information technology in it." Jouranl Of Science and Technology Policy (JSTP) 7, no. 1 (2015): 47-68.

Mousavi, Seyed Hossein, Ebrahim Salehi Omran, Maghsoud Ferasatkhah, and Jafar Towfiqi. "Presenting the development model of Entrepreneur University in 
Iran." Quarterly Journal of Engineering Education in Iran 19, no. 76 (2017): $1-28$.

Mousavi, Seyyed Hossein, Ibrahi, Salehi Omran, Seyyed mahsa Mousavi, and Maghsoud Ferasatkhah. "Identifying the Barriers to Entrepreneurial University Ecosystem Development." Journal of Teaching in Marine Sciences 6, no. 4 (2019): 35-51.

Nabipour, Iraj. "The Fifth Generation University: Based on the Quintuple Helix of Carayannis and Campbell." Iran South Medical Journal 23, no. 2 (2020): 165-194.

Naghavi, Seyaed Ali, and Hamed Falah. "Investigating the Relationship between University and Industry through an Entrepreneurial Approach. Paper presented at the, Babolsar: Taro." National Conference on Entrepreneurship and Knowledge-Based Business Management. Babolsar: North Tarod Research Institute, 2012.

Nozari, Hamzeh, and Alireza Karimi. "The role of formal and informal relations (social relations network) in the employment of students of Kharazmi University." Social walfare, 2017: 17(64),159-194.

Ogilvy, James, and Peter Schwartz. Plotting Your Scenarios. In L. Fahey \& R. Randall (Eds.), Learning from the Future. Edited by L. Fahey \& R. Randall. California: John Wiley \& Sons, 1998.

Perkin, Harold. History of Universities. Vol. 18, in International Handbook of Higher Education, by Harold Perkin, Filip Altbach, \& Jaems Forest. Dordrecht: Springer, 2007.

Peters, Guy, Giliberto Capano, Michael Howlett, Ishani Mukherjee, Meng-Hsuan Chou, and Pauline Ravinet. Designing for Policy Effectiveness: Defining and Understanding a Concept. Cambridge University Press, 2018.

Rahmani, Ramin, and Ali Nazari Tavakoli. "The challenges of the higher education system in relation to the employment of graduates." The first conference on employment and the countrys higher education system. Tehran: Tarbiat amodares university, 2003.

Renjen, Punit, and Sarah Brown. Preparing tomorrow's workforce for the Fourth Industrial Revolution / For business: A framework for action. Deloitte Global and the Global Business Coalition, 2018, 16.

Rubins, Ira. "Risks and Rewards of Academic Capitalism and the Effects of Presidential Leadership in the Entrepreneurial University." Perspectives in Public Affairs, 2007: 3-18.

Salehi O, Ebrahim, and Hosein Chaharbashlou. "Studying University-Industry Relations in Iran: A Comparative Study Based on Successful Countries' Experiences." First International Conference on Management, Futures, Entrepreneurship and Industry in Higher Ed. Sanandaj: Kordestan University, 2011. 15.

Sam, Chanphirun, and Peter van der Sijde. "Understanding the concept of the entrepreneurial university from the perspective of higher education models." Higher Education 68, no. 6 (2014): 891-908. 
Samari, Eisa, Mohammad Yamani Dozi Sarkhabi, Ebrahim Salehi Omran, and golam Reza Geraei Nezhad. "Investigating and identifying the effective factors in the process of "university development" in Iranian public universities." Educational planning syudies 2, no. 4 (2014): 67-100.

Sarv, Mohammad Soheil, Jafar Hezarjeribi, Mohammad Taghi Karami Ghahi, and Ardashir Entezari. "The Ratio of Higher Education Development Policies and School Demand." Social development and walfre planning 11, no. 41 (2020): 33-72.

Secretariat of the Board of Supervision, Evaluation and, Quality Assurance of the University in Khuzestan. 5 3, 2020. http://scu.ac.ir/web/nezaratostan.

Shahid Chamran University of Ahvaz. 5 3, 2020. http://scu.ac.ir/.

Sharifi A. M., Fatemeh, Abasalt Khorasani, Kourosh Fathi V., and Ebrahim Salehi O. "Employability skills of Academic Graduates: an Exploratory Mixed Approach." Journal of Theory \& Practice in Curriculum 13, no. 7 (2019): 29-52.

Swanger, Dustin. July 2018. https://www.fmcc.edu/about/files/2018/08/The-Futureof-Higher-Education-in-the-US2.pdf.

Tindemans, Bruno , and Vickie Dekocker. "The Learning Society." OECD.org. September 2020. https://www.oecd.org/publications/oecd-skills-strategyflanders-9789264309791-en.htm.

UNESCO. Higher education in Europe: Thematic reflections on higher education. Vol. 29. 2004.

UNESCO. Rethinking Education towards a golobal common good. United Nations Educational, Scientific and Cultural Organization, 2015.

Wilson, Patricia. "Embracing Locality in Local Economic Development." Urban Studies 32, no. 4-5 (1995): 645-658.

Yaghoubi, Mahmoud, and Hossein Motahharenejad. "The main requirements in developing Iranian engineering training strategies." Iranian of engineering education, 2011: 13(51),31-51.

\section{About the authors}

HAMID FARHADI RAD (corresponding author, h.farhadirad@scu.ac.ir) is an associate professor in the Department of Education at the Shahid Chamran University of Ahvaz (Khuzestan, Iran). He is particularly interested in issues concerning Educational Administration, Higher education \& Qualitative research methods. He studied Educational Administration at the University of Tehran and spent a term as a visiting fellow in the International Center for Higher Education Research (INCHER) Kassel University in 2009-2010. Hamid has ten years of teaching experience at the university in the field of higher education management, higher education policy-making, and educational economic. His main area of research is higher education management and leadership. He is a member of the strategic planning board for the future of the university in the Shahid Chamran University of Ahvaz, Iran. Hamid is the head of the Quality Assurance Office at the Shahid Chamran University of Ahvaz, 
Iran 2018 to present. He conducted various research projects in the field of higher education, for example, designing a model for paying and spending grants at the university, developing a model for institutional accreditation and evaluation, and participating in the development of the second strategic plan of the Shahid Chamran University of Ahvaz.

HASAN FARAZMAND (hfrazmand@scu.ac.ir), is Professor of economics at Shahid Chamran University of Ahvaz (Khuzestan, Iran) and has been the head of the Faculty of Economics and Social Sciences since 2016. He received his Ph.D. in International Economics in 2015 and then worked as a faculty member at Shahid Chamran University of Ahvaz. He has been a member of many specialized groups and committees inside and outside the university. For Example; a member of the Scientific Council of The Journal of the Assembly and Research, 2001 to 2004, Vice Chancellor for Finance at Shahid Chamran University of Ahvaz from 2017 to 2019. His main field of research is international development economics, and he has led many projects in this field. For example: Industrial Development of Khuzestan Province, Designing Development Plan, Productivity in public and private sector of Khuzestan Province, and Investigation of the Impact of Oil Revenues on Social and Cultural Development of Khuzestan Province.

MORTEZA AFGHAH (m.afghah@scu.ac.ir), is an associate professor of economics at Shahid Chamran University of Ahvaz (Khuzestan, Iran) and has been the head of the Department of Economics from 2018 to the present. His main area of research interest is economic development and he has done many works in this field. For example; the role of education in the economics and social development of the country, evaluation of the Iranian Scientific and Industrial Research Organization and scientific poles: goals, structures, and challenges. He has also been a member of various committees and specialized groups such as the Dean of the Faculty of Economics and Social Sciences from 1992 to 1994, and a member of the Productivity Committee of Khuzestan Province 2018 to 2020. Calculation of Human Development Index of Iranian Provinces and Its Impact on Economic Growth and Employment of the Provinces (Fuzzy Logic Approach), Calculation of Human Development Index (HDI) and its relationship with corruption in Khuzestan province, and Investigating the Mutual Relationship between Private and Public Educational and Health Care Expenditures with the Economic Growth of Iran (A Causality Approach) are examples of thesis under his supervision.

YAGHOOB ANDAYESH (andayesh230@scu.ac.ir) holds a Ph.D. in Economics, trends in financial economics, resource economics, and the environment from University of Tabriz (Iran). He is an assistant professor in the Department of Economics, Shahid Chamran University of Ahvaz (Khuzestan, Iran). He is interested in the Economics of Development and was an Expert in the Office of Subsidies of the Ministry of Welfare and Social Security, Iran from 2004 to 2007. Yaghoub conducted works such as "Multidimensional Child Poverty and a Study of the Bangladesh Experience" by the Deputy Minister of Social 
Welfare, Ministry of Labor Cooperation and Social Welfare; Effects of the first phase of subsidy targeting on the health sectors and the cost of living index of households" Ministry of Health 2011 and, Study on the elimination of food and medicine subsidies on the cost of living index of households, Management and Planning Organization of the country. He is interested in working on the relationship between university and entrepreneurship in Khuzestan province, and in this study, he helped our team identifying entrepreneurial capabilities in Khuzestan province. 


\title{
University in an oil-dependent state economy: The future of Khuzestan higher education
}

\author{
Hamid Farhadi Rad, Hasan Farazmand, \\ Morteza Afghah, and Yaghoob Andayesh
}

doi: http://dx.doi.org/10.18543/tjhe-9(1)-2021pp157-198

\section{Copyright}

Copyright for this article is retained by the Publisher. It is an Open Access material that is free for full online access, download, storage, distribution, and or reuse in any medium only for noncommercial purposes and in compliance with any applicable copyright legislation, without prior permission from the Publisher or the author(s). In any case, proper acknowledgement of the original publication source must be made and any changes to the original work must be indicated clearly and in a manner that does not suggest the author's and or Publisher's endorsement whatsoever. Any other use of its content in any medium or format, now known or developed in the future, requires prior written permission of the copyright holder. 